\title{
Editorial
}

\section{No inviertes en educación, pagas las consecuencias}

\author{
If you do not invest in education, you pay the consequences
}

Si se quiere sacar a un país de la pobreza, del subdesarrollo, de los problemas sociales-marginación, conflictos, delincuencia, inseguridad y un largo etcétera-, hay que proporcionarle educación. Si se quiere tener una sociedad más justa, más equitativa, más solidaria, más humana, con más y mejores oportunidades para llevar una vida más plena, y que sea más dueña de su destino, igualmente necesita educación. Si se quiere erradicar la ignorancia y el analfabetismo, el mercantilismo y el consumismo, la superstición y los prejuicios de la población también ha de hacerse a través de la educación. Si se quiere liberar a las personas del fanatismo y la manipulación, la alienación y la enajenación, la opresión y la explotación igualmente se hará por medio de la educación.

Pareciera que todos esos males se combaten con una sola receta, que todos esos maleficios y demonios pueden exorcizarse con un solo conjuro, y que todos esos caminos retorcidos pueden enderezarse a través de ese proceso de formación y transformación llamado educación, y así es. Pero la educación no es una varita que transforma por obra de magia ni es una medicina que obra milagros de la noche a la mañana, ni tampoco es gratis. La educación implica un proceso de largo aliento... es una tarea compleja y... costosa.

La educación, como todas las cosas en este mundo, conlleva un costo. Como toda actividad humana implica recurso humano calificado -muy calificado-, infraestructura, equipo y materiales, tiempo, metas claramente definidas, procesos, organización y sistematización y una base financiera sólida que la sustente. Igualmente debe asumirse que una educación de mejor calidad implica un mayor costo económico. El hecho es que la educación no es una actividad que resulte barata ni mucho menos gratis, aún si la provee una escuela 
pública. Por tanto, si se quiere educación han de asumirse en serio sus costos y si se quiere la mejor educación posible ha de entenderse que hay que pagar mucho más por ella.

La ecuación costo-beneficio de la educación es simple, clara, contundente e incontrovertible -se explica y justifica por sí misma. La inversión que se haga o deje de hacer en educación se traduce, para bien o para mal, en resultados tangibles y concretos en los niveles de vida de las personas y en el desarrollo de los pueblos. La inversión que se hace en educación luego retorna a la población como un activo social que incide positiva o negativamente en ella. Por eso, si se cree que la educación es una necesidad accesoria y postergable, que supone un lujo y por tanto un costo gravoso o "un gasto", que ante una diversidad de necesidades acaso más urgentes -salud, seguridad y trabajo, por ejemploy unos recursos económicos limitados, el país no puede permitirse, debería considerarse el costo para la sociedad de no invertir en ella.

Si no se invierte en educación, la sociedad pierde un derecho legítimo e inalienable y el país se estanca, se atrasa y flota a la deriva. Si se recortan los recursos económicos en educación, se reduce la oportunidad de todo un pueblo a construir un mejor país y soñar con un mejor futuro personal. Si se asigna un presupuesto exiguo para educación, a la sociedad sólo se le puede procurar una educación exigua y mediocre. Si no se prioriza la educación de entre otros rubros en la vida nacional, se condena a todo un país al eterno subdesarrollo, ya que no hay desarrollo sin educación, sin buena educación. Sin educación los pueblos pierden su identidad, su conciencia social y su memoria histórica.

Si se roba, se pierde o se administra ineficientemente el dinero asignado a educación, se roba y se pierde el futuro de un niño, de muchos niños, de toda una generación. Si se inventa un sistema educativo de caricatura con el cual se "entretiene" a niños y jóvenes, igual, el país pierde porque la educación es una actividad comprometida y no se improvisa. Si para educación se asigna un presupuesto del quinto mundo, obtienes una educación del quinto mundo para construir un país del quinto mundo con ciudadanos de quinta categoría. Si no se invierte en educación, todos los males y demonios mencionados al inicio no sólo se hacen presentes, sino que se entronizan en las sociedades, creando y perpetuando sistemas y mundos perversos. No invertir en educación es el boleto más seguro para regresar al oscurantismo medieval.

Los pueblos sin educación -cuyo indicador más significativo es un retroceso o un estancamiento educativo sostenido-, como bien lo expresa Fernando Bárcenas (El Nuevo Diario.com.ni, 13 de febrero 2013), son pueblos con vocación a la extinción donde las personas emigran de sus sociedades fallidas, y quienes 
remanan, degeneran en muchedumbre viciosa e irracional -como la tribu de los Yahoos de Borges y los Yahoos de Jonathan Swift. El sistema democrático, a su vez, degenera en cacicazgos -gobierno con mesías incluido que, garrote en mano, se cree el ungido e iluminado y además indispensable-, plutocracia-donde los ricos gobiernan al país como si fuera su finca y que además se creen los únicos capaces y los únicos con derecho de gobernar- u oclocracia-gobierno de los demagogos y corruptos que no tienen formación ni preparación y explotan la ignorancia de las masas para encarnar sus intereses particulares. Un declive en la educación de un pueblo garantiza la anomia y la ingobernabilidad.

Como bien lo reportan las estadísticas internacionales, los países que menos invierten educación tienen los sistemas educativos más ineficientes, menores niveles de rendimiento escolar, menor cobertura, menores niveles de escolaridad, menor calidad de la educación, índices más altos de analfabetismo, repitencia y deserción escolar. Sin educación -o con educación de baja calidad-, las personas fallan en desarrollar plenamente sus talentos, sus valores humanos y sus competencias laborales con base a los cuales puedan construir un entorno más convivible y proyectarse en un futuro prometedor y más esperanzador. De aquí que un pueblo sin educación es un pueblo sin futuro.

Los países que menos invierten en educación se ubican en los últimos lugares en los indicadores de desarrollo humano y en general tienen menor nivel de bienestar social y menor calidad de vida los cuales se hacen evidentes en la vida cotidiana. Como hemos de entender, resulta mucho más caro, mucho más oneroso no invertir en educación en la cuantía que los retos presentes y futuros demandan y que la población necesita y merece. Ese escenario trágico y catastrófico, consecuencia de no invertir en educación, es válido no sólo para una sociedad y un país, sino también muy válido para una familia y para un individuo en particular.

En una sociedad donde se reconoce que la mayor riqueza de un pueblo es su gente, es también necesario reconocer que ésta sólo es riqueza en la medida de su educación; de lo contrario, igual puede ser una caja de pandora, una carga social o una bomba (social) de tiempo. Por tanto, debe quedar claro que, si no se invierte en educación, todos pagamos las consecuencias. 